\title{
Global warming and Bergmann's rule: do central European passerines adjust their body size to rising temperatures?
}

\author{
Volker Salewski • Wesley M. Hochachka • \\ Wolfgang Fiedler
}

Received: 1 January 2009 / Accepted: 27 July 2009 / Published online: 1 September 2009

(C) The Author(s) 2009. This article is published with open access at Springerlink.com

\begin{abstract}
Recent climate change has caused diverse ecological responses in plants and animals. However, relatively little is known about homeothermic animals' ability to adapt to changing temperature regimes through changes in body size, in accordance with Bergmann's rule. We used fluctuations in mean annual temperatures in south-west Germany since 1972 in order to look for direct links between temperature and two aspects of body size: body mass and flight feather length. Data from regionally born juveniles of 12 passerine bird species were analysed. Body mass and feather length varied significantly among years in eight and nine species, respectively. Typically the interannual changes in morphology were complexly non-linear, as was inter-annual variation in temperature. For six (body mass) and seven species (feather length), these inter-annual fluctuations were significantly correlated with temperature fluctuations. However, negative correlations consistent with Bergmann's rule were only found for five species, either for body mass or feather length. In several of the
\end{abstract}

Communicated by Heli Siitari.

Electronic supplementary material The online version of this article (doi:10.1007/s00442-009-1446-2) contains supplementary material, which is available to authorized users.

V. Salewski $(\bowtie) \cdot$ W. Fiedler

Max-Planck-Institute for Ornithology,

Vogelwarte Radolfzell, Schlossallee 2,

78315 Radolfzell, Germany

e-mail: salewski@orn.mpg.de

W. M. Hochachka

Laboratory of Ornithology, Cornell University,

159 Sapsucker Woods Road, Ithaca, NY 14850, USA

e-mail:wmh6@cornell.edu species for which body mass and feather length was significantly associated with temperature, morphological responses were better predicted by temperature data that were smoothed across multiple years than by the actual mean breeding season temperatures of the year of birth. This was found in five species for body mass and three species for feather length. These results suggest that changes in body size may not merely be the result of phenotypic plasticity but may hint at genetically based microevolutionary adaptations.

Keywords Global warming $\cdot$ Birds $\cdot$ Morphology · Phenotypic plasticity $\cdot$ Microevolution

\section{Introduction}

Diverse ecological changes have occurred in response to rising global temperatures (Hughes 2000; Houghton et al. 2001) over the last century. Changes in communities include shifts in tree lines (Payette 2007), altered species composition in the North Sea (Hiddink and ter Hofstede 2008) and changes in species assemblages due to range shifts of mobile species, such as butterflies (Parmesan et al. 1999) and birds (Thomas and Lennon 1999). Even species remaining in the same area can be affected by climate change, for example, through altered timing of life history events as has been observed in diverse taxa such as Eurasian taiga trees (Delbart et al. 2008), Mediterranean butterflies (Peñuelas et al. 2002), and birds, for which both earlier breeding (Dunn 2004) and changes in migration timing have been seen (e.g. Fiedler 2003; Tøttrup et al. 2006). In some cases, we know that changing phenology can affect other species, as seen in the growing mismatch between times of caterpillar emergence and breeding of pied 
flycatchers (Ficedula hypoleuca) and great tits (Parus major) in the Netherlands (Both et al. 2004; Visser et al. 2004). Overall, documented responses to climate change are abundant, as seen in multiple review papers on this subject (e.g. Hughes 2000; Walther et al. 2002; Parmesan and Yohe 2003).

Effects of climate change on morphology are relatively undocumented, and apparently rarely studied ; for example, Root et al. (2003) only list nine such studies of the 143 reviewed. Nevertheless, changes in morphology, as with changes in phenology, are expected responses to altered climates. The expectation that climate will affect morphology is based largely on observed variations in morphology across longer time intervals and through space (e.g. Barnosky et al. 2003; Millien et al. 2006). For example, patterns of changing size of homeothermic animals are expected to follow Bergmann's rule (1847, p. 638: within a genus the smaller species should live in a warmer and the larger species in a colder climate), with selection to adjust heat dissipation altering body surface:volume ratios. While strictly Bergmann's rule refers to variation in sizes of species within genera, Rensch (1938) reformulated Bergmann's rule to populations within a species. Hereafter we will use "Bergmann's rule" to refer to this within-species variation. While questions have been raised about whether body sizes of homeotherms will respond to changing temperatures (for contradictory evidence in North American mammals see McNab 1971; Ashton et al. 2000), considerable evidence exists of differences in body size through space along gradients of temperature: in a recent meta-analysis Meiri and Dayan (2003) found that $72 \%$ of all bird species $(n=94)$ and $65 \%$ of all mammal species $(n=149)$ examined showed a pattern following the predictions of Bergmann's rule. Changes in body size have been described within populations of some bird species in recent decades (e.g. Ludwichowski 1997; Tornberg et al. 1999; Jakober and Stauber 2000). Bergmann's rule has been invoked to explain correlations between changes in climate and size in some of these cases (Yom-Tov 2001; Yom-Tov et al. 2006).

However, a clear causal link between changing temperatures and changes in body size cannot be presumed without eliminating other causes of systematic variation in body size; direct selection based on the thermal environment [Bergmann's (1847) rule] also needs to be distinguished from less direct effects of climate on morphology when such patterns are found. Changes in environments, cooccurring with but independent of climate change, can alter aspects of animals' sizes; examples include changes in diet (Tornberg et al. 1999), habitat quality (Richner et al. 1989; Ohlsson and Smith 2001; Searcy et al. 2004; Garant et al. 2005) and predation risk (Gosler et al. 1995; Naef-Daenzer et al. 2001). Studies are needed that can disentangle effects of climate change from the effects of other systematic changes in environments in recent decades. Previous studies linking changes in temperature and birds' morphology (Yom-Tov 2001; Yom-Tov et al. 2006) implicitly assumed simple (linear or quadratic) changes in both temperatures and response, thus weakening the strengths of conclusions that could be drawn. One potentially viable approach to providing strong inferences that morphology varies with changing temperatures is to focus on irregularities in the rate of recent temperature increases, looking for these same inter-annual irregularities to appear in variation in body sizes.

Also interesting would be the identification of the cause of any variation in size. Gienapp et al. (2008) have speculated that most if not all morphological responses to climate change will be the result of phenotypic plasticity and not changes in genetic composition of populations. If this is true then we would expect inter-annual variation in body size of fully grown juveniles to be linked with variation in average temperatures experienced by these birds as they grew, but not with variation of temperatures over a longer time period that would select for changes in phenotype due to both genetic components of size and phenotypic plasticity.

Here, we test the hypothesis that body size of birds decreases in times of global warming, the pattern predicted by Bergmann's rule, by examining inter-annual variation in body sizes of fully grown juvenile birds. We further test whether body size is more highly correlated with temperatures during the breeding season in which the birds were raised or with a long-term average temperature. We make use of the fact that temperatures have not increased consistently over the last 35 years in south-western Germany to provide the data to strongly infer effects of climate on morphology. We examined data from 12 species of passerines to look at the generalities of the patterns that we find. Changes in both mass and length of flight feathers are examined in our analyses. Our results indicate that the average sizes of juveniles of some species do vary among years in association with changing temperatures, but that this pattern was not statistically detected in the majority of the species examined.

\section{Materials and methods}

Data from mist netting

Our data come from birds captured in mist netting as part of an ongoing monitoring effort on the Mettnau peninsula $\left(47.729^{\circ} \mathrm{N}, 8.998^{\circ} \mathrm{E}\right)$, Lake Constance, near Radolfzell in south-western Germany. The study area covers about $1 \mathrm{~km}^{2}$ and includes various habitats, but predominantly shrubland, 
wet meadows and reed beds. Since 1972 the mist-netting protocol has remained essentially unchanged, using $52 \mathrm{mist}$ nets $(6 \mathrm{~m})$ in a single transect that are set following standardized methods from 30 June to 6 November (Berthold and Schlenker 1975; Berthold et al. 1991). The only years in which mist netting was not conducted were 1987 and 1999. All mist-netted birds are identified to species, ringed, aged, the time of capture recorded, primary and body molt categorized, and standard measurements taken. Body masses of all birds were determined with an electronic scale with a precision of $0.1 \mathrm{~g}$. The length of the third outermost primary feather (hereafter "feather length") was measured following Berthold and Friedrich (1979).

Previous work has shown that body mass and morphological characters related to flight may vary with age (e.g. Alatalo et al. 1984; Norman 1997; Pérez-Tris and Tellerría 2001). Therefore, we considered only fully grown first-year birds in our analyses, because it is usually not possible to determine the exact age of older individuals. We did not separate the sexes for the analyses because sex could not be determined for juveniles of many species. Only the data from the first capture were used. We assume that amongyear variation in sex ratios is negligible. We selected all species for which more than 1,000 first-year individuals were captured, and plotted cumulative percentages of mistnetted individuals on each day of the mist-netting season. Then we defined all birds as regionally (south-west Germany and adjacent areas) born that were mist netted either before the day when a distinct increase in capture numbers occurred, or before the day after which a second increase in numbers occurred for species for which regionally born birds show an influx at the very beginning of the mist-netting season. We interpreted these increases as influxes of non-regional birds, e.g. migrants from north-eastern Europe. Finally, we excluded all species for which an insufficient number of birds was mist netted (below ten first-year regionally born individuals in many years). For some species, not all morphological data were collected in every year.

We analysed data from the following 12 species (the date before which birds were classified as being local is give in parentheses): dunnock Prunella modularis (7 September), robin Erithacus rubecula (1 September), song thrush Turdus philomelos (16 September), blackbird Turdus merula (25 September), garden warbler Sylvia borin (18 July), blackcap Sylvia atricapilla (23 August), reed warbler Acrocephalus scirpaceus (14 July), willow warbler Phylloscopus trochilus (23 July), chiffchaff Phylloscopus collybita (23 September), great tit Parus major (31 August), blue tit Cyanistes caeruleus (15 August), and reed bunting Emberiza schoeniclus (14 September). With respect to migration distance, garden warblers, reed warblers and willow warblers are long-distance migrants wintering in sub-Saharan Africa. Dunnocks, robins, song thrushes, chiffchaffs and reed buntings are short-distance or partial migrants that winter not further than the Mediterranean region or only some individuals of the population migrate. Blackbirds, great tits and blue tits are mainly resident in the region although some individuals may also migrate short distances.

\section{Temperature data}

Our temperature data are based on standardised daily measurements taken at Konstanz $\left(47,667^{\circ} \mathrm{N}, 9,183^{\circ} \mathrm{E}\right)$ by the Deutscher Wetterdienst, approximately $18 \mathrm{~km}$ from the study site (http://www.dwd.de/de/FundE/Klima/KLIS/ daten/online/nat/index_standardformat.htm) between 1973 and 2006. Annual mean temperatures were calculated from the daily mean temperatures in each year. Mean breeding season temperatures were calculated from daily mean temperatures in April, May and June, the main breeding period for the species concerned.

Mean annual temperatures increased significantly between 1972 and 2006 by $0.05^{\circ} \mathrm{C}$ per year (linear regression on annual means: $t=5.426, P<0.001$, adjusted $\left.R^{2}=0.456\right)$. However, annual mean temperatures have not changed linearly. Within the overall increase in average temperatures, we observed distinct multi-year decreases in temperatures in the late 1970s, the early 1990s, and again in the most recent years (Fig. 1). These non-linear patterns were verified when year-to-year variation in mean temperature was modelled as a spline in a generalized additive model (GAM). We fit this, and all other GAMs described in

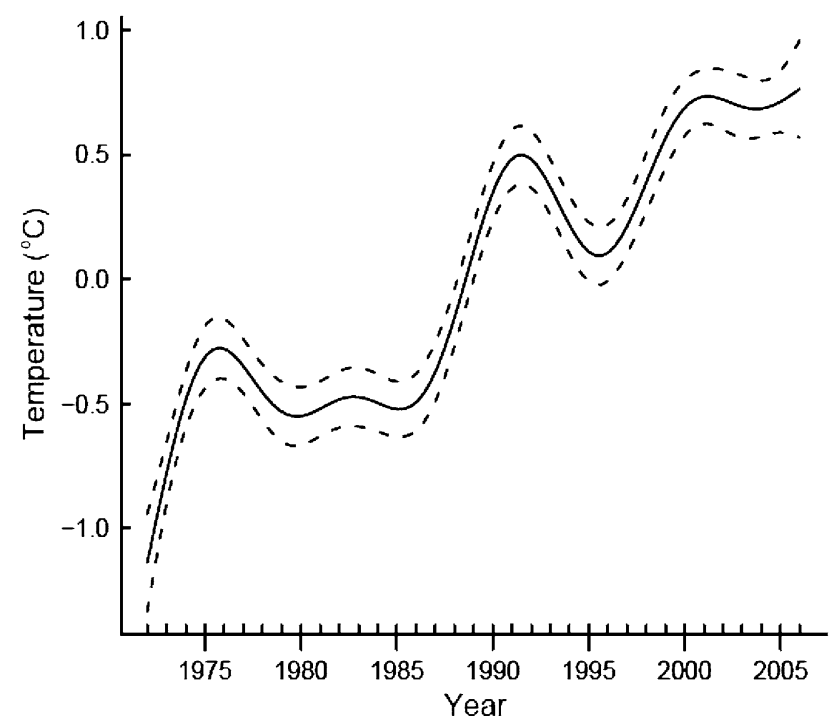

Fig. 1 Trend of mean annual temperatures in Konstanz between 1972 and 2006 from a generalized additive model (GAM) of mean annual temperatures against year. The solid line is the regression spline fit from a GAM, and dashed lines are $95 \%$ confidence intervals 
this paper using the mgcv library (Wood 2006) in the program R (R Development Core Team 2007).

We used two representations of annual mean temperatures in our analyses of associations between temperature and body size. First, we directly used annual mean breeding season temperatures in statistical analyses of association between temperature and morphology. Juvenile birds which grow under "good" conditions can grow larger (Alatalo and Lundberg 1984; Ardia 2005). Thus, we expect that a correlation of size with breeding season temperature will represent phenotypic plasticity of body size, with body size influenced by the environmental conditions experienced by individual birds. However, body size also has an inherited component (e.g. Boag and Grant 1978; Merilä and Gustafsson 1996) and therefore selection on multiple generations of birds over periods of consistently changing climate could result in temperature-related changes in body size being most apparent when examining temperatures averaged across multiple years (Hallett et al. 2004). To examine this possibility, we also created our second temperature measure, a smoothed version of the mean annual temperature data, using a moving-averages smoother. This smoother, the T4253 smoother, starts with a running median of four sequential values, which is centered by a running median of two temperatures. Then the values are re-smoothed by applying a running median of 5 and a running median of 3 . Residuals are computed by subtracting the smoothed series from the original series. The process is then repeated on the computed residuals. The final smoothed residuals are computed by subtracting the smoothed values obtained in the first iteration (Norušis 2005). A correlation of this smoothed temperature trend with the body size of juveniles could be indicative of a genetic influence on body size, because the smoothed temperatures describe typical conditions experienced by multiple generations and not necessarily the conditions directly experienced by the birds being measured.

While temperature-based selection may be more apparent in winter than in the breeding season, we did not relate birds' sizes to the mean temperatures in January, the coldest month in the study area because mean annual and mean breeding season temperatures are relevant to all species that we considered, including migrants.

\section{Analyses of morphological data}

The longest time series of morphological data that we have are for body mass (measured since 1972) and feather length (measured since 1974). In only four of the 12 species were annual average mass and feather length significantly correlated (bivariate Pearson's correlation: garden warbler, $r=0.423, P=0.018$; willow warbler, $r=0.529, P=0.002$; chiffchaff, $r=0.356, P=0.050 ;$ great tit, $r=0.688$,
$P=0.003)$. Therefore, we used both as parallel indicators of size, recognizing that mass is not necessarily an adequate surrogate for size (Piersma and Davidson 1991), and that even combining information from multiple morphological traits into a single "size" index will be inadequate to describe the potentially complex changes in morphology that could take place through time. While ornithologists are not in agreement on what single measure, if any, best reflects body size (e.g. Gosler et al. 1998; Rising and Somers 1989; Freeman and Jackson 1990), often either wing length (highly correlated with feather length, Berthold and Friedrich 1979; Jenni and Winkler 1989; own analysis, wing length data available from 1996 onwards, linear regression of wing length on feather length: $R^{2}$ between 0.546 in reed warbler and 0.829 in reed bunting, $P<0.001$ for all species) or body mass are considered.

We only analysed data from regional pre-migratory birds (see above) for two reasons. First, migratory birds can double their body mass due to pre-migratory fuel deposition (Bairlein 2002) and can change their body composition when preparing for migration (e.g. Piersma and Gill 1998; Bauchinger and Biebach 2005). In examining only premigratory birds, variation in body mass due to different fuel loads and body composition was assumed to be negligible. Pre-migratory status is confirmed by the fact that on a nineunit scale for estimating subcutaneous fat stores (Kaiser 1993) more than $95 \%$ of the birds whose data were used in our analyses showed low scores between 0 and 3 (unpublished data, regularly available from 1993 onwards; see also Kaiser 1992). Second, wing morphology may differ in birds from different populations due to different migratory distances travelled (Leisler and Winkler 2003; Fiedler 2005). Therefore, the inclusion of migrating birds from north-eastern populations (the assumed origin of non-regional migrants) could bias the results.

\section{Body mass}

Our analyses needed to account for the possibility that several nuisance factors would obscure inter-annual variation in body mass. Mass of passerines can vary with the time of the day (Lehikoinen 1987; Gosler 1994; Macleod et al. 2005), ambient temperature (Lehikoinen 1987; Macleod et al. 2005), season (Lehikoinen 1987; Gosler 1994; Macleod et al. 2005) and moult (Ellegren and Fransson 1992; Kaiser 1992; Gosler 1994). Our first analyses were designed to describe changes in expected mass through the years for each species, after accounting for these other sources of variation. We fit data on masses of individual birds using a GAM in which year was a smoothing parameter. The nuisance parameters time when a bird was mist netted (time; hours after the beginning of civil twilight), temperature (mean daily temperature of the day when a bird 
was mist netted), day (day of the respective mist-netting season when a bird was mist netted) and moult (birds were assigned to be either in moult when more than 20 feathers on the breast, belly or back were growing and/or when they were in primary moult) were entered as fixed effects. All variables except year and moult were treated as continuous covariates; year and moult were fixed, categorical factors. We assume that systematic annual changes in mean body mass are not confounded by daily variation in temperature during the mist-netting season, because daily body mass changes in response to fluctuations in daily temperature during the netting season are the result of birds adjusting food intake to short-term requirements (Gosler 2002; Macleod et al. 2005). Effectively, we are assuming that daily fluctuations in mass with changes in temperature represent a consistent source of noise around a latent typical mass across all years. We believe that this assumption is reasonable because daily temperatures during the mist-netting season and annual mean temperatures were not highly correlated $\left(R^{2}=0.010\right.$ between all daily temperatures during the ringing season and their associated annual mean temperatures).

Second, we examined the extent to which inter-annual changes in mass were associated with changes in average ambient temperatures. In this second set of analyses we replaced the year effect with ambient temperature, conducting two separate linear regression analyses for each species: one with smoothed mean annual temperatures and the second with mean breeding season temperatures as independent variables additional to nuisance factors. We determined which of the representations of temperature was a better predictor of changes in body mass by assessing support for the two models using Akaike's information criterion (AIC) values.

\section{Feather length}

Feather length was measured by many different people and previous studies have documented consistent inter-ringer variation in wing-related measurements (Gosler et al. 1995, 1998). Unfortunately the identities of people taking measurements were only recorded in our database for the years 1996-2006. If we were to use data from all available years, including those for which we did not know ringers' identities, we needed to understand the effect of not accounting for observer biases. Therefore, we investigated whether the observer biases were minimal using feather length as the independent variable in a linear mixed model (calculated with SPSS) with year (1996-2006) as a fixed factor and ringer as a random factor. The magnitude of a ringer effect was calculated as the proportion of the residual variance (variance unexplained by fixed effects) that was accounted for by inter-ringer differences. Many ringers were present at the study site over multiple years and there are usually a number of shared years for many ringers. However, we restricted this analyses to main effects only, as preliminary analyses revealed that there were no significant interactions between the variables "year" and "ringer".

Variance in measurements of feather length due to the ringer effect was in general very low and varied between $0 \%$ (garden warbler) and 29\% (song thrush) of the total random + error variance in the data (Table 1). Additionally the ringer effect was only significant for the blackcap, the chiffchaff and the reed bunting (Wald tests, $P<0.05$ ). However, in these three species the ringer effect was less than $8 \%$ of the total random + error variance and the estimated marginal mean of the feather length without the ringer effect always differed by less than $0.3 \mathrm{~mm}$ from the mean of the original measurements and was in 20 out of 30 cases (years) below $0.1 \mathrm{~mm}$ (unpublished data). Therefore, we assume that inter-ringer variation would have minor impact on annual mean feather length values. Because no relevant ringer effect was found in the period between 1996 and 2006 we assumed that any such effect would also be negligible in the earlier years of the study.

As with our analyses of variation in mass, we used GAMs to describe patterns of year-to-year variation in feather length, using feather length as the independent variable and year as a smoothing parameter. After this, we tested which of our two measures of annual temperature, the breeding-season temperatures or the smoothed annual mean temperatures, best accounted for the observed interannual variation in feather length.

A criterion for statistical significance of $P \leq 0.05$ was used for all analyses. For the comparison of models using AIC, a value $<2$ for $\triangle \mathrm{AIC}$ was assumed to indicate no difference between models, a value between 2 and 5 was an indication that the models may differ and a value of $>5$ was an indication that the model with the smaller index certainly explains the data better compared to the model with the higher index (Burnham and Anderson 2002; Johnson and Omland 2004). Years were treated as independent data points as there was no autocorrelation of the data for temperatures (mean annual temperature, Durbin Watson test, $d=1.704, n=35, P<0.05$, statistical significance indicates lack of autocorrelation; mean annual breeding season temperature, Durbin Watson test, $d=2.450, n=34, P<0.05$ ), mass (Durbin Watson test, $d=1.543-2.056, n=32, P<0.05)$ or feather length (Durbin Watson test, $d=1.651-2.018, n=31, P<0.05$ ) between years. Statistical analyses were either done with the program SPSS 12.0 or the program $\mathrm{R}$ version 2.5.1. (R Development Core Team 2007). 
Table 1 Importance of consistency in among-ringer differences in measurement of feather length (ringer biases)
Results are from generalised mixed models, conducted separately for each species' data, with year as the fixed factor and ringer identity as a random effect. Shown are residual ("error") and ringer variances (Ringer), their SEs, their proportion of the total (ringer + residual) variances, and $Z$ - and $P$-values of a Wald statistic for the statistical significance of inter-ringer differences in average measurements

\begin{tabular}{|c|c|c|c|c|c|c|}
\hline Species & & Covariance & SE & $\begin{array}{l}\text { Total } \\
\text { co-variance }(\%)\end{array}$ & Wald $Z$ & $P$ \\
\hline \multirow[t]{2}{*}{ Dunnock } & Residual & 2.001 & 0.391 & 83 & 5.120 & $<0.001$ \\
\hline & Ringer & 0.409 & 0.335 & 17 & 1.222 & 0.222 \\
\hline \multirow[t]{2}{*}{ Robin } & Residual & 2.678 & 0.157 & 97 & 17.087 & $<0.001$ \\
\hline & Ringer & 0.088 & 0.075 & 3 & 1.181 & 0.237 \\
\hline \multirow[t]{2}{*}{ Song thrush } & Residual & 2.781 & 0.733 & 71 & 3.596 & $<0.001$ \\
\hline & Ringer & 1.162 & 0.863 & 29 & 0.347 & 0.178 \\
\hline \multirow[t]{2}{*}{ Blackbird } & Residual & 8.667 & 0.811 & 91 & 10.693 & $<0.001$ \\
\hline & Ringer & 0.816 & 0.605 & 9 & 1.349 & 0.177 \\
\hline \multirow[t]{2}{*}{ Garden warbler } & Residual & 2.335 & 0.275 & 100 & 8.485 & $<0.001$ \\
\hline & Ringer & 0 & - & 0 & - & - \\
\hline \multirow[t]{2}{*}{ Blackcap } & Residual & 2.234 & 0.083 & 92 & 26.890 & $<0.001$ \\
\hline & Ringer & 0.196 & 0.065 & 8 & 3.015 & 0.003 \\
\hline \multirow[t]{2}{*}{ Reed warbler } & Residual & 2.192 & 0.116 & 98 & 18.926 & $<0.001$ \\
\hline & Ringer & 0.049 & 0.055 & 2 & 0.881 & 0.378 \\
\hline \multirow[t]{2}{*}{ Willow warbler } & Residual & 4.834 & 0.495 & 95 & 9.766 & $<0.001$ \\
\hline & Ringer & 0.274 & 0.289 & 5 & 0.949 & 0.342 \\
\hline \multirow[t]{2}{*}{ Chiffchaff } & Residual & 5.340 & 0.129 & 97 & 41.292 & $<0.001$ \\
\hline & Ringer & 0.157 & 0.064 & 3 & 2.473 & 0.013 \\
\hline \multirow[t]{2}{*}{ Great tit } & Residual & 3.226 & 0.212 & 96 & 15,238 & $<0.001$ \\
\hline & Ringer & 0.125 & 0.091 & 4 & 1.378 & 0.168 \\
\hline \multirow[t]{2}{*}{ Blue tit } & Residual & 2.695 & 0.148 & 93 & 18.171 & $<0.001$ \\
\hline & Ringer & 0.203 & 0.109 & 7 & 1.856 & 0.063 \\
\hline \multirow[t]{2}{*}{ Reed bunting } & Residual & 6.117 & 0.254 & 95 & 24.109 & $>0.001$ \\
\hline & Ringer & 0.296 & 0.131 & 5 & 2.263 & 0.024 \\
\hline
\end{tabular}

Table 2 Statistical significance of year-to-year variation in body mass for the passerine species investigated

\begin{tabular}{|c|c|c|c|c|}
\hline Species & $n$ & $F$ & $P$ & Adjusted $R^{2}$ \\
\hline Dunnock & 557 & 0.365 & 0.546 & 0.294 \\
\hline Robin $^{\mathrm{a}}$ & 1571 & 3.665 & $<0.001$ & 0.253 \\
\hline Song thrush & 228 & 0.810 & 0.369 & 0.265 \\
\hline Blackbird $^{\mathrm{a}}$ & 1167 & 2.676 & 0.004 & 0.307 \\
\hline Garden warbler & 325 & 1.693 & 0.112 & 0.113 \\
\hline Blackcap $^{a}$ & 4440 & 5.643 & $<0.001$ & 0.336 \\
\hline Reed Warbler ${ }^{\mathrm{a}}$ & 1657 & 7.440 & $<0.001$ & 0.116 \\
\hline Willow warbler ${ }^{\mathrm{a}}$ & 1451 & 3.894 & $<0.001$ & 0.196 \\
\hline Chiffchaff $^{\mathrm{a}}$ & 8938 & 10.760 & $<0.001$ & 0.226 \\
\hline Great tit & 877 & 1.519 & 0.195 & 0.214 \\
\hline Blue tit $^{\mathrm{a}}$ & 2201 & 6.111 & $<0.001$ & 0.195 \\
\hline Reed bunting & 4037 & 0.271 & 0.603 & 0.113 \\
\hline
\end{tabular}

Shown are the sample sizes, $F$ - and $P$-values of the smoothing term (year), and the adjusted $R^{2}$ from generalized additive models (GAM)

${ }^{a}$ Species for which the inter-annual variation was statistically significant

some striking similarities: increases in feather length in the early 1970s, the late 1980s and the early 2000s. Decreases in feather lengths in the early 1980s and the early 1990s resulted in local troughs in the graphs in the mid 1980s and 
Fig. 2 Trends in body mass at a constant-effort mist-netting site at Radolfzell, southern-western Germany, between 1973 and 2006. Shown are the estimated trends fit by GAMs with year as the smoothing term; $95 \%$ confidence intervals are plotted as dashed lines around the estimated trend. For details about factors and covariates included in the models see text and Table 1
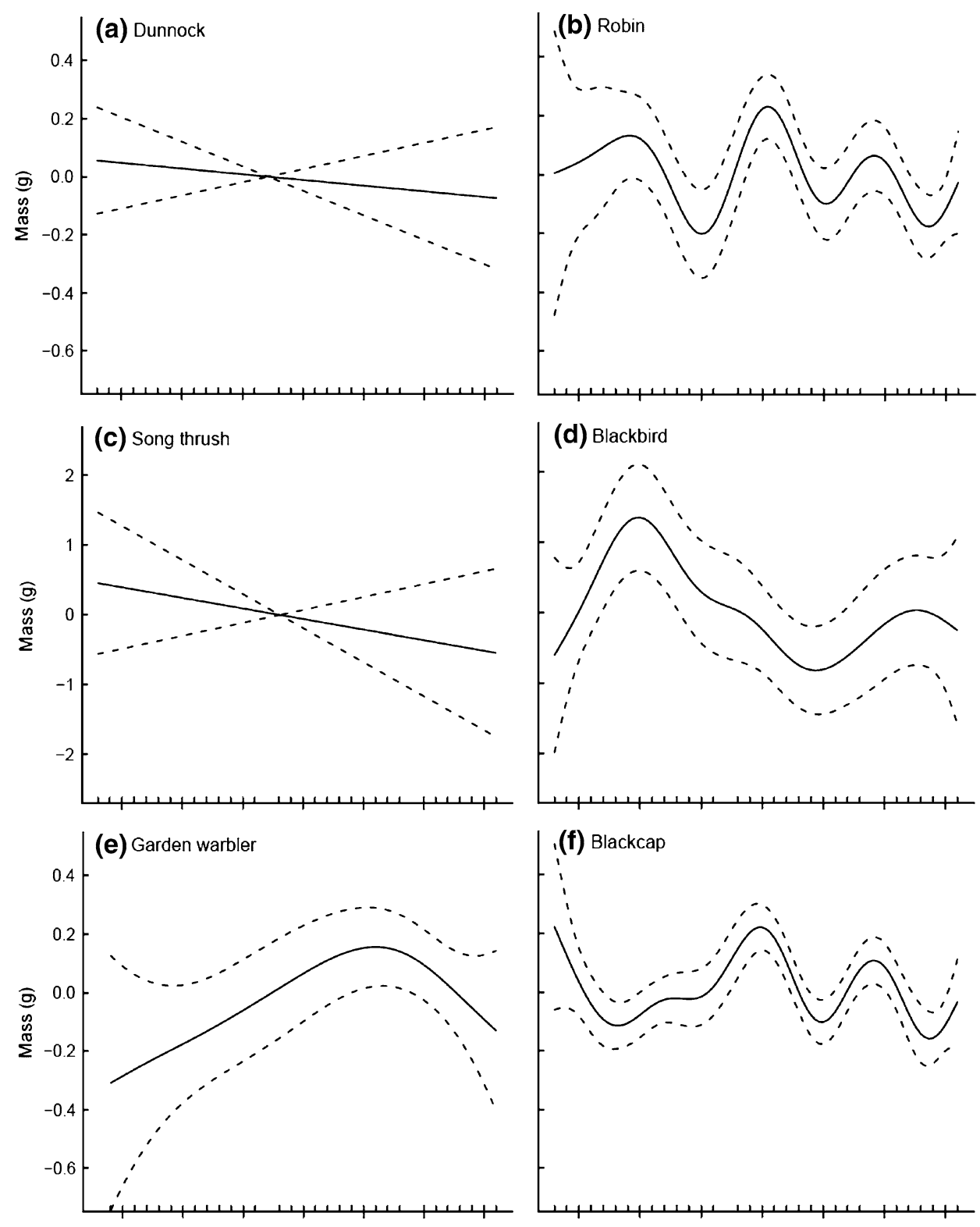

late 1990s, respectively (Fig. 3). This pattern was especially pronounced in the significant trends for robin, blackcap, reed warbler, great tit and blue tit (Fig. 3b, f, g, j, k). The increases in average feather length were especially steep from the early 2000s onwards with feather lengths at their longest for the entire study period. Other species displayed only some of these fluctuations in feather length; for example, willow warbler (Fig. 3h) and chiffchaff (Fig. 3i) only displayed increasing feather lengths in the early 1970s and the decreases in the mid 1980s.

Variation in morphology with changing annual temperatures

Changes in mass were significantly associated with at least one temperature variable in six out of seven species that displayed significant inter-annual variation in average mass (Table 4; Appendix 1). For three out of these six species, mean breeding season temperature as well as smoothed annual temperatures were significantly correlated with body mass (reed warbler, chiffchaff, blue tit; Appendix 1), with higher temperatures associated with lower average mass. For these three species with significant associations for both temperature variables, the regression with smoothed mean annual temperature had $\Delta$ AIC values $<6$ below the model including mean breeding season temperature (Table 4), indicating a higher influence of the long-term variable on body mass compared to the short-term variation in temperature described in the raw annual mean breeding season temperatures. For two of the remaining three species, blackbirds and willow warblers, the average body mass was significantly lower 
Fig. 2 continued
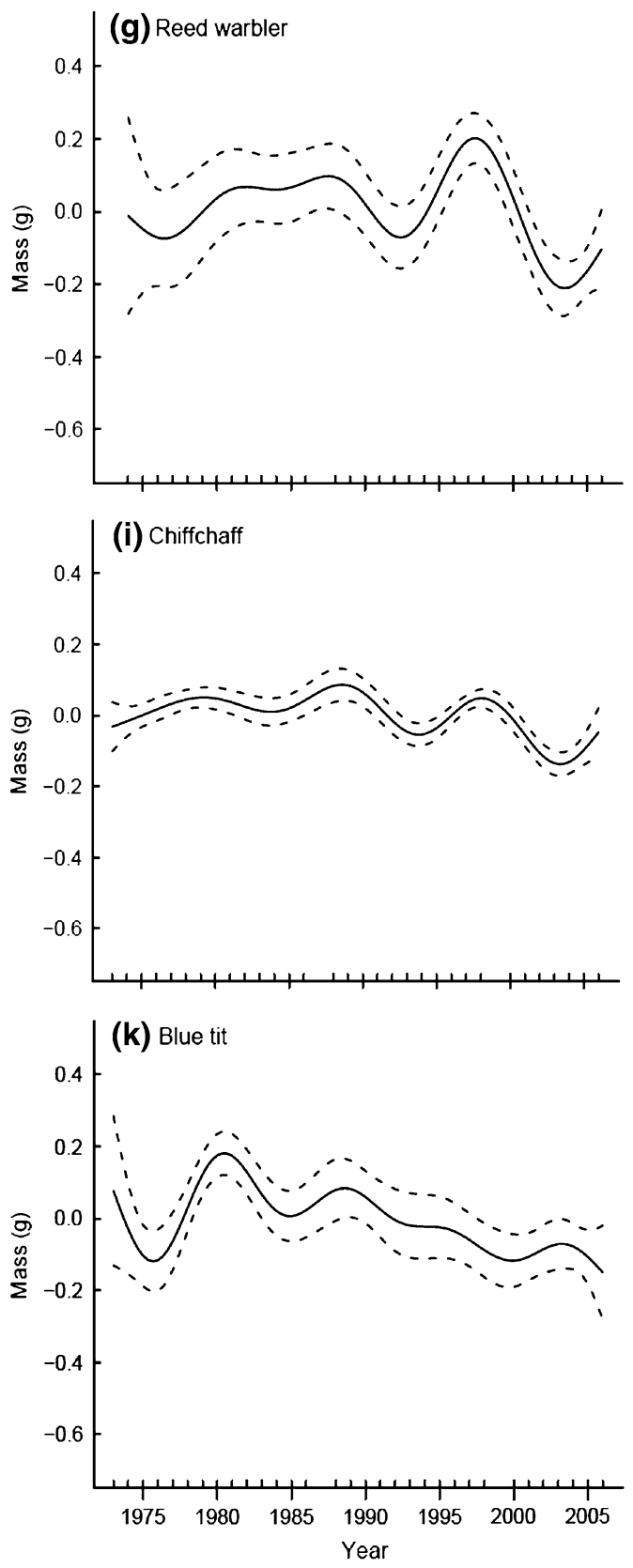
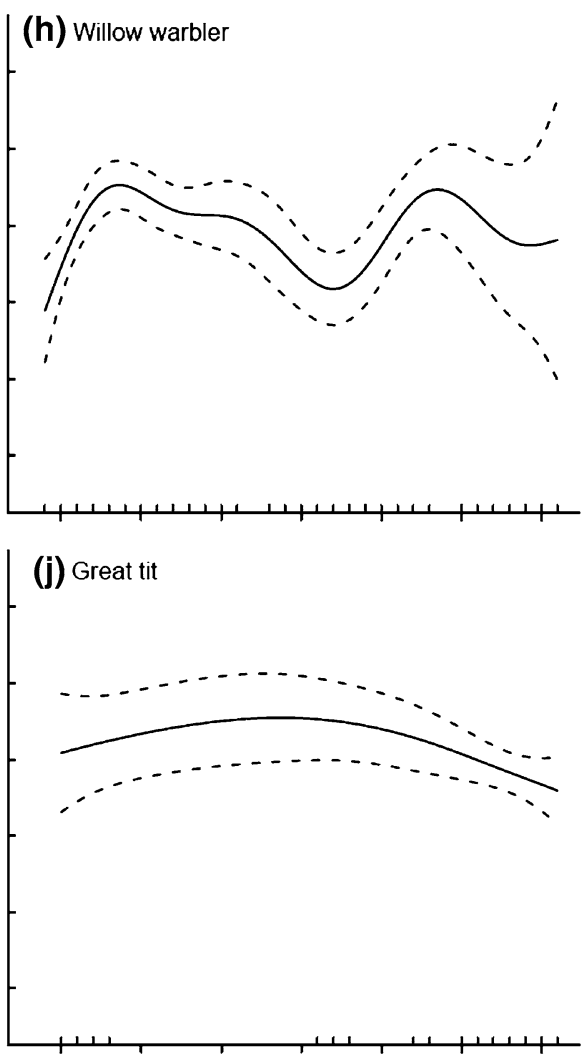

(I) Reed bunting

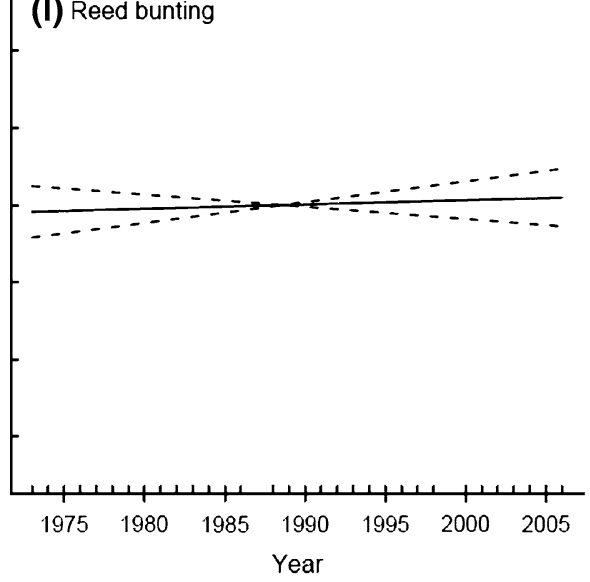

when smoothed annual temperatures were higher. However, the body mass of the final species, the blackcap, was significantly higher in years with higher breeding season temperature.

Feather length was significantly associated with at least one temperature variable in seven out of nine species that displayed significant inter-annual variation, although these relationships never explained more than $1 \%$ of all variance in feather length (Table 4; Appendix 2). Effects of both mean breeding season temperatures and smoothed mean annual temperatures were significant for six species (Appendix 2). In species for which both temperature variables explained statistically significant amounts of variation in feather length, smoothed annual temperatures better explained (lower AIC values, $\Delta \mathrm{AIC}>5$ ) inter-annual variation in feather length in the blackbird and the chiffchaff, but variation in breeding season temperatures was better supported for the blackcap and the reed warbler. In the willow warbler and the blue tit the values for both models were effectively identical. Additionally, mean feather length of robins varied significantly with smoothed annual mean temperatures but not with breeding season temperatures. For five species with significant relationships (blackcap, reed warbler, willow warbler, chiffchaff and blue tit), average 
Table 3 Statistical significance of inter-annual variation in feather length (length of third outermost primary feather) for the species included in this study

\begin{tabular}{lrrrc}
\hline Species & \multicolumn{1}{l}{$F$} & \multicolumn{1}{l}{$P$} & Adjusted $R^{2}$ \\
\hline Dunnock & 531 & 0.857 & 0.463 & $<0.001$ \\
Robin $^{\mathrm{a}}$ & 1,535 & 3.936 & $<0.001$ & 0.017 \\
Song thrush & 266 & 1.256 & 0.261 & 0.012 \\
Blackbird $^{\mathrm{a}}$ & 1,131 & 4.000 & $<0.001$ & 0.024 \\
Garden warbler $^{\mathrm{a}}$ & 307 & 2.080 & 0.031 & 0.036 \\
Blackcap $^{\mathrm{a}}$ & 4,390 & 12.920 & $<0.001$ & 0.024 \\
Reed warbler $^{\mathrm{a}}$ & 1,527 & 9.455 & $<0.001$ & 0.048 \\
Willow warbler $^{\mathrm{a}}$ & 1,406 & 4.561 & $<0.001$ & 0.022 \\
Chiffchaff $^{\mathrm{a}}$ & 8,717 & 13.080 & $<0.001$ & 0.012 \\
Great tit $^{\mathrm{a}}$ & 856 & 4.751 & $<0.001$ & 0.039 \\
Blue tit $^{\mathrm{a}}$ & 2,149 & 9.125 & $<0.001$ & 0.033 \\
Reed bunting & 3,756 & 1.659 & 0.093 & 0.002 \\
\hline
\end{tabular}

Shown are the $F$ - and $P$-values, and the adjusted $R^{2}$ of the smoothing term (year) from GAM

${ }^{a}$ Species for which the inter-annual variation was statistically significant

feather length declined with higher temperatures. However, with robins and blackbirds, individuals increased feather length with increasing temperatures during the study period.

In both the analyses for mass as well as for feather length we may not have had the statistical power to detect all biologically real effects of temperature on morphology. The possibility of low statistical power is suggested because statistical power decreases with lower sample sizes, and we found that sample sizes were larger for species for which statistical significance was found $(P=0.03$ for mass and $P=0.02$ for feather length; both from onetailed Mann-Whitney $U$-tests).

\section{Discussion}

For most of the bird species examined, the average masses and feather lengths varied from year to year since 1973, and typically this inter-annual variation was non-linear and complex. We found that in approximately half of the species both mass and feather length varied statistically significantly with temperature and that in many of these relationships body size decreased with higher temperatures. However, significant decreases in size with increasing temperatures were only found for five species, either for body mass or feather length, yielding little support for a general and strong adaptation to climate change based on thermal constraints (i.e. Bergmann's rule). Our interpretation contrasts with that of Yom-Tov et al. (2006) of the results from a study in Great Britain. There, an increasing trend in body mass of passerines as an adaptation to global warming was assumed, although only six of 14 species showed significant trends in size through time, and not always consistently between two study sites.

Our results provide a more direct and robust examination of effects of temperature on birds' morphologies than previous work because we directly associated morphology with temperature instead of only assuming a systematic variation in morphology through time. Finding direct associations between changes in temperature and morphology is important, because ambient temperature is not the only potential environmental factor which may effect the body size of birds. Several studies have demonstrated changes in morphology through time, and inferred causes unrelated to changes in climate. Decreasing as well as increasing body size of goshawks in Finland and in Denmark were discussed as adaptations to changing diets rather than to changing temperatures (Tornberg et al. 1999; Yom-Tov and Yom-Tov 2006). The possibility that the decreases in body mass in four out of five passerine species in Israel between 1950 and 1999 could track changes in food availability was also not excluded by Yom-Tov (2001). The wing lengths of dippers Cinclus cinclus in Spain increased between 1985 and 2005 which was discussed as an adaptation to a changing water regime instead of a direct response to rising temperatures (Moreno-Ruedo and Rivas 2007). Morphology of a species can also vary among habitats (Ulfstrand et al. 1981; Blondel 2007), and therefore, changes in morphology could also track changes of habitat in a given study area throughout the study period. Unfortunately, data on factors like changes in habitat availability and structure (Garant et al. 2005; Blondel 2007) or fluctuations in food quality and quantity as well as fluctuating pressures from predators are not available from our study region.

Temperatures can be indexed in many different ways, although we believe that our chosen temperature indices were appropriate. Meiri and Dayan (2003) suggested that extreme winter temperatures exert a high selective pressure on body size. Supporting this argument, Meiri and Dayan (2003) showed that a significantly greater proportion of sedentary bird species conformed with the predictions of Bergmann's rule. However, such extreme temperatures are avoided by migrants. In our study there was no clear evidence that migration determined whether a species' morphology would be affected by inter-annual variation in temperatures. The body mass of the long-distance migrant garden warbler showed a strong increasing trend until the late 1990s. However, reed warblers and willow warblers also winter in tropical Africa, but did not increase their body mass throughout the study period. Therefore, different migration strategies of the species did not clearly explain the results of our analyses although the number of long-distance migrants considered here is too low to draw a general conclusion. 
Fig. 3 Trends in feather length (length of third outermost primary feather) at a constant-effort mist-netting site at Radolfzell, southern-western Germany, between 1974 and 2006. Shown are the estimated trends fit by GAMs with year as the smoothing term; $95 \%$ confidence intervals are plotted as dashed lines around the estimated trend
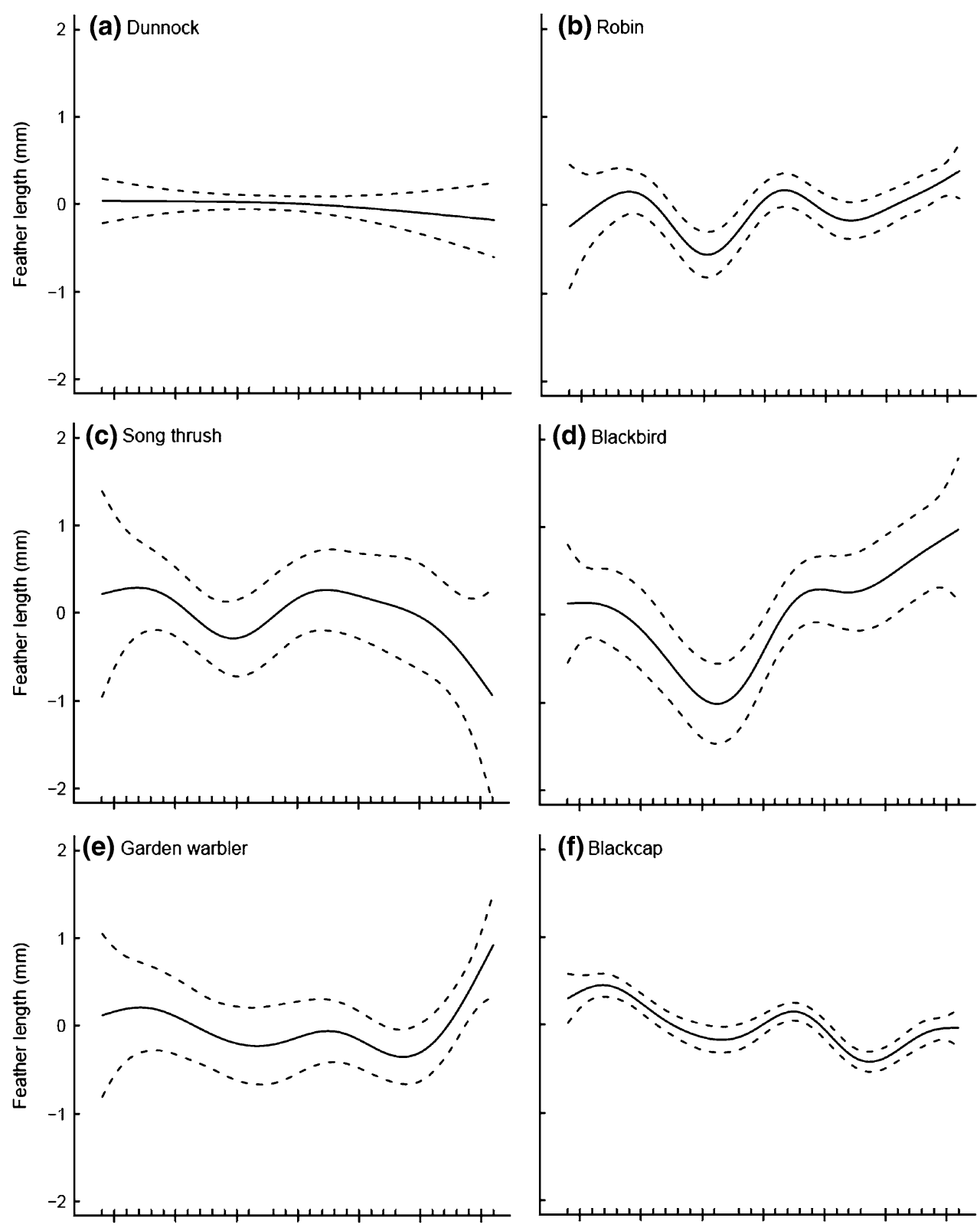

Interpreting the response of feather length to changing temperatures is potentially more complicated than interpreting variation in body mass. The failure of Yom-Tov et al. (2006) to detect a general trend in wing length as expected according to Allen's rule (Allen 1877: “...a marked tendency to enlargement of peripheral parts under high temperature, or towards the tropics...") may partly be due to an apparent conflict between two geographically varying selection pressures. Gosler et al. (1998) described wing length (highly correlated with feather length; Berthold and Friedrich 1979; Jenni and Winkler 1989) as the best general measure of body size. Whereas wing length should decrease in association with increasing temperatures according to Bergmann's rule, the same measurement is expected to increase under the same conditions according to Allen's rule. Additionally, conventional wing length measurements (Svensson 1992) measure the length of the carpal bones (subject to thermoregulatory needs according to either Bergmann's or Allen's rule, and to factors related to flight performance like migration, microhabitat selection, foraging ecology, predator avoidance) in conjunction with the longest distal flight feathers (dead tissue not subject to selection with respect to thermoregulatory needs), and therefore represents a combination of traits on which different selection pressures may act. For example, longer wing length is associated with greater migration distances (e.g. Pérez-Tris and Tellerría 2001; Leisler and Winkler 2003; Fiedler 2005). Further, evidence is accumulating that migrant bird species reduce migration distances and/or the proportion of migrating individuals in populations in 
Fig. 3 continued
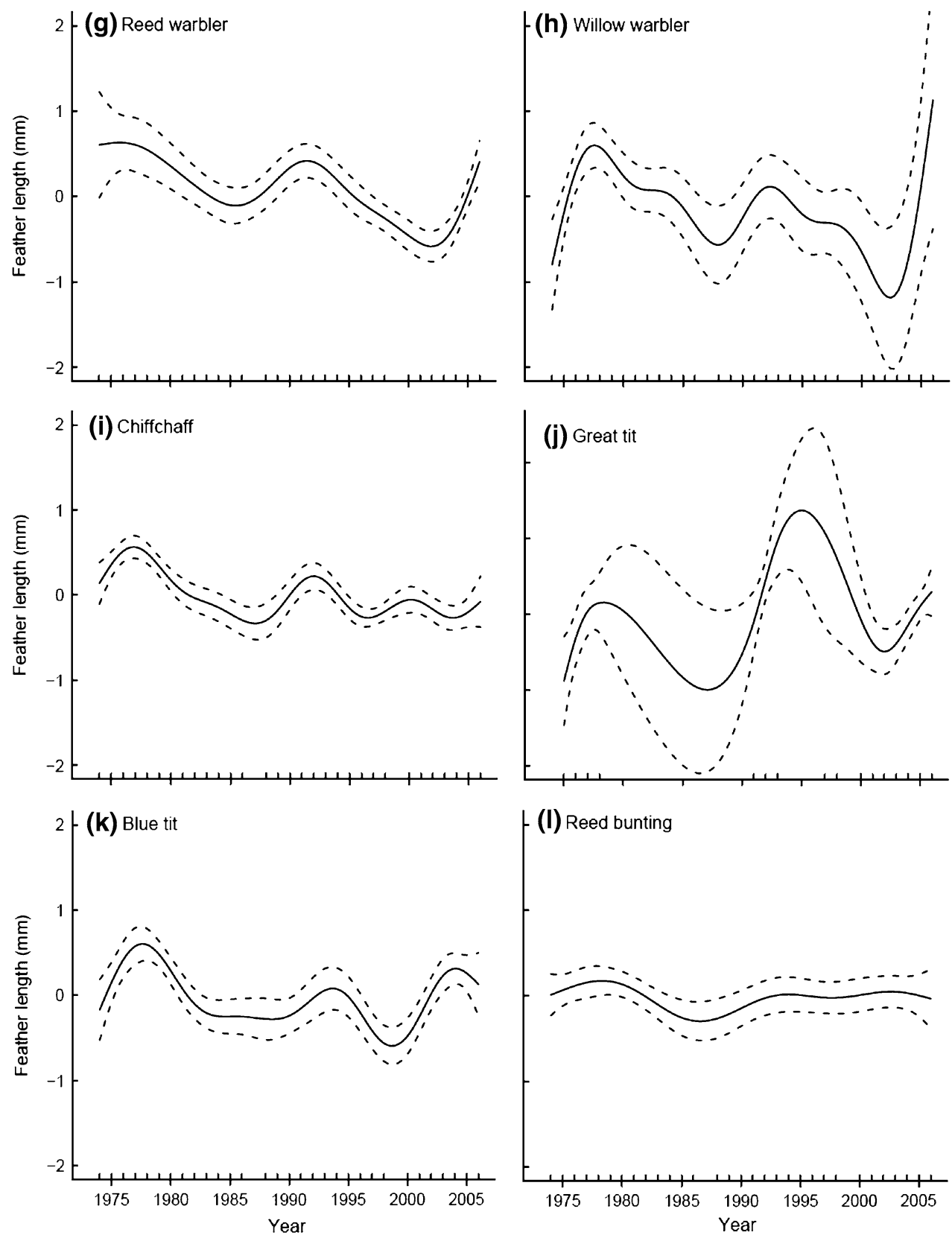

connection with global warming (Fiedler 2003; Gordo et al. 2007). Therefore, climate-mediated changes in migratory behaviour may be affecting the wing lengths of some of the species that we examined.

Regardless of the cause of morphological variation, response to environmental heterogeneity could either indicate that selection has resulted in genetically based adaptations, or in purely phenotypic responses (Blondel 2007). Examples where the influence of ecological conditions on body mass and morphological traits has been shown include mallards Anas platyrhynchos (Pehrsson 1987), pied flycatchers Ficedula hypoleuca (Alatalo and Lundberg 1984) and song sparrows Melospiza melodia (Hochachka and Smith 1991). That birds can regulate their mass according to perceived predation risk has been shown in empirical studies, e.g. by Gosler et al. (1995) or Lilliendahl (1997), and the impact of predation on fledglings may result in selection for high body mass (Naef-Daenzer et al. 2001). However, morphological traits of birds such as body mass, wing length and tarsus length also have heritable components (Boag and Grant 1978; Smith and Wettermark 1995; Jensen et al. 2003), and thus the observed associations with climatic variation may have a genetic basis. For example, Nowakowski (2000) discusses inter-annual variation in wing length of reed warblers as a consequence of directional selection caused by aspects of climate. There are 
Table 4 Effects of mean breeding season temperatures and smoothed annual mean temperatures on inter-annual variation in body mass and in feather length

\begin{tabular}{lcc}
\hline Species & $\begin{array}{c}\Delta \text { AIC body } \\
\text { mass models }\end{array}$ & $\begin{array}{c}\Delta \text { AIC feather } \\
\text { length models }\end{array}$ \\
\hline Dunnock & -3.37 & -2.45 \\
Robin & 0.31 & $7.48^{\mathrm{a}}$ \\
Song thrush & 0.17 & -0.06 \\
Blackbird & $3.59^{\mathrm{a}}$ & $5.73^{\mathrm{a}}$ \\
Garden warbler & -2.33 & 0.91 \\
Blackcap & $-32.63^{\mathrm{a}}$ & $-11.79^{\mathrm{a}}$ \\
Reed warbler & $7.91^{\mathrm{a}}$ & $-20.13^{\mathrm{a}}$ \\
Willow warbler & $7.01^{\mathrm{a}}$ & $0^{\mathrm{a}}$ \\
Chiffchaff & $6.73^{\mathrm{a}}$ & $27.4^{\mathrm{a}}$ \\
Great tit & 1.36 & 2.73 \\
Blue tit & $8.51^{\mathrm{a}}$ & $-0.06^{\mathrm{a}}$ \\
Reed bunting & -0.92 & 0.08
\end{tabular}

Shown are the $\triangle$ Akaike's information criterion $(\triangle A I C)$ values of the two linear regression models either with mean breeding season temperature or with smoothed annual mean temperature as independent variables. Negative values indicate that the model containing mean breeding temperature has the lower AIC value, positive values indicated that the model containing the smoothed annual temperature has the lower AIC value. Details of the models are found in Appendices 1 and 2

${ }^{a}$ At least one temperature variable has a significant effect on body mass or feather length

hints in our study that significant changes in body size associated with temperature are not caused by phenotypic plasticity alone. When the association of body mass or feather length with at least one temperature variable was significant (13 cases), the AIC value was lower (i.e. the model a better predictor) for breeding season temperature compared to smoothed annual temperatures only in three cases. In eight cases the AIC value was lower for smoothed annual temperatures, suggesting that the long-term temperature trend has a higher influence on average body size in a population than the conditions during the breeding season in which the birds were raised. These results may indicate selection for birds' sizes across multiple generations, which would be genetically based. However, our data cannot be used to establish selection on genetic variation in size and the extremely low $R^{2}$-values in the association of feather length with temperature show that variation of this trait is mainly caused by other factors not considered in this study.

In conclusion, although our results indicate that morphology of birds can respond rapidly to changes in environmental temperatures, this was detected only in a minority of the investigated species. Therefore, we were not able to detect a general trend for body size changes in birds as a reaction to global warming during the last decades, either one caused directly by adaptation to a changing thermal environment
(Bergmann's rule) or otherwise. Potentially, our failure to find general responses to temperature fluctuations is the result of patterns that were too subtle to discover given our existing data. Treating latitude as a surrogate for temperature, Hughes (2000) estimated that a $3^{\circ} \mathrm{C}$ change in mean annual temperature corresponds to a shift in isotherms of approximately $300-400 \mathrm{~km}$ in latitude. The application of this estimate to the study area would correspond to a southward shift of approximately $150 \mathrm{~km}$ during the study period. Studies which found a general association of body size with latitude usually considered much larger ranges (Gould and Johnston 1972; Groen and Yurlov 1999; Storz et al. 2001) as well as longer time scales (Smith and Betancourt 2003; Yom-Tov 2001). Therefore, our study period may have been too short, the magnitude of climatic changes too low and/or microevolutionary processes too slow to detect larger or more consistent changes in body size over the period of 34 years. While changes in phenology which are matching fine-scale patterns of climate change (Møller et al. 2006) have been noted in south-western German birds (Bergmann 1999; Gatter 2000; Peintinger and Schuster 2005), we found less consistent evidence that their sizes have changed. Nevertheless, our results suggest more evidence of a morphological response to changing climate may be found if global temperatures continue to rise as predicted (Houghton et al. 2001).

Acknowledgments We thank the members of the Vogelwarte Radolfzell and the more than 200 volunteers who have been keeping the ringing station on the Mettnau peninsula running for 35 years and who collected the data for this study.

Open Access This article is distributed under the terms of the Creative Commons Attribution Noncommercial License which permits any noncommercial use, distribution, and reproduction in any medium, provided the original author(s) and source are credited.

\section{References}

Alatalo RV, Lundberg A (1984) Density-dependence in breeding success of the pied flycatcher (Ficedula hypoleuca). J Anim Ecol 53:969-977

Alatalo RV, Gustafsson L, Lundberg A (1984) Why do young passerine birds have shorter wings than older birds. Ibis 126:410-415

Allen JA (1877) The influence of physical conditions in the genesis of species. Rad Rev 1:108-140

Ardia DR (2005) Super size me: an experimental test of the factors affecting lipid content and the ability of residual body mass to predict lipid stores in nestling European starlings. Funct Ecol 19:414-420

Ashton K, Tracy MC, de Queiroz A (2000) Is Bergmann's rule valid for mammals? Am Nat 156:390-415

Bairlein F (2002) How to get fat: nutritional mechanisms of seasonal fat accumulation in migratory songbirds. Naturwissenschaften 89:1-10

Barnosky AD, Hadly EA, Bell CJ (2003) Mammalian response to global warming on varied temporal scales. J Mammal 84:354-368

Bauchinger U, Biebach H (2005) Phenotypic flexibility of skeletal muscles during long-distance migration of garden warblers: muscle 
changes are differentially related to body mass. Ann NY Acad Sci 1046:271-281

Bergmann C (1847) Über die Verhältnisse der Wärmeökonomie der Thiere zu ihrer Größe. Göttinger Stud 1:595-708

Bergmann F (1999) Langfristige Zunahme früher Bruten beim Teichrohrsänger (Acrocephalus scirpaceus) in einem südwestdeutschen Untersuchungsgebiet. J Ornithol 140:81-86

Berthold B, Friedrich W (1979) Die Federlänge: ein neues nützliches Flügelmaß. Vogelwarte 30:11-21

Berthold P, Schlenker R (1975) The "Mettnau-Reit-Illmitz-Program" ("MRI-Program"), a long-term bird trapping program of the Vogelwarte Radolfzell. Vogelwarte 28:1-123

Berthold P, Fliege G, Heine G, Querner U, Schlenker R (1991) Wegzug, Rastverhalten, Biometrie und Mauser von Kleinvögeln in Mitteleuropa. Vogelwarte 36:1-221

Blondel J (2007) Coping with habitat heterogeneity: the story of Mediterranean blue tits. J Ornithol 148(Suppl. 1):3-15

Boag PT, Grant PR (1978) Heritability of external morphology in Darwin's finches. Nature 274:793-794

Both C, Artemyev AV, Blaauw B, Cowie RJ, Dekhuijzen AJ, Eeva T, Enemar A, Gustafsson L, Ivankina EV, Järvinen A, Metcalfe NB, Nyholm NEI, Potti J, Ravussin P-A, Sanz JJ, Silverin B, Slater FM, Sokolov LV, Török J, Winkel W, Wright J, Zang H, Visser ME (2004) Large-scale geographical variation confirms that climate change causes birds to lay earlier. Proc R Soc Lond B 271:1657-1662

Burnham KP, Anderson DR (2002) Model selection and multimodel inference: a practical information-theoretic approach, 2nd edn. Springer, New York

Delbart N, Picard G, Le Toans T, Kergoat L, Quegan S, Woodward I, Dye D, Fedotova V (2008) Spring phenology in boreal Eurasia over a nearly century time scale. Global Change Biol 14:603-614

Dunn M (2004) Breeding dates and reproductive performance. In: Møller A, Fiedler W, Berthold P (eds) Effects of climate change in birds. Elsevier, Amsterdam, pp 69-87

Ellegren H, Fransson T (1992) Fat loads and estimated flight-ranges in four Sylvia species analysed during autumn migration at Gotland, south-east Sweden. Ringing Migr 13:1-12

Fiedler W (2003) Recent changes in migratory behaviour of birds: a compilation of field observations and ringing data. In: Berthold $\mathrm{P}$, Gwinner E, Sonnenschein E (eds) Avian migration. Springer, New York, pp 21-37

Fiedler W (2005) Ecomorphology of the external flight apparatus of blackcaps (Sylvia atricapilla) with different migration behaviour. Ann NY Acad Sci 1046:253-263

Freeman S, Jackson WM (1990) Univariate metrics are not adequate to measure avian body size. Auk 107:69-74

Garant D, Kruuk LEB, Wilkin TA, McCleery RH, Sheldon BC (2005) Evolution driven by differential dispersal within a wild bird population. Nature 433:60-65

Gatter W (2000) Vogelzug und Vogelbestände in Mitteleuropa. AULA, Wiebelsheim

Gienapp P, Teplitsky C, Alho JS, Mills JA, Merilä J (2008) Climate change and evolution: disentangling environmental and genetic responses. Mol Ecol 17:167-178

Gordo O, Sanz JJ, Lobo JM (2007) Spatial pattern of white stork (Ciconia ciconia) migratory phenology in the Iberian Peninsula. J Ornithol 148:293-308

Gosler A (1994) Mass change during moult in the great tit Parus major. Bird Study 41:146-154

Gosler AG (2002) Strategy and constraint in the winter fattening response to temperature in the great tit Parus major. $\mathrm{J}$ Anim Ecol 71:771-779

Gosler AG, Greenwood JJD, Perrins C (1995) Predation risk and the cost of being fat. Nature 377:621-623
Gosler AG, Greenwood JJD, Baker JK, Davidson NC (1998) The field determination of body size and condition in passerines: a report to the British Ringing Committee. Bird Study 45:92-103

Gould SJ, Johnston RF (1972) Geographic variation. Annu Rev Ecol Syst 3:457-498

Groen NM, Yurlov AK (1999) Body dimensions and mass of breeding and hatched black-tailed godwits (Limosa l. limosa): a comparison between a West Siberian and a Dutch population. J Ornithol 140:73-79

Hallett TB, Coulson T, Pilkington JG, Clutton-Brock TH, Pemberton JM, Grenfell BT (2004) Why large scale climate indices seem to predict ecological processes better than local weather. Nature 430:71-75

Hiddink JG, ter Hofstede R (2008) Climate induced increases in species richness of marine fishes. Global Change Biol 14:453-460

Hochachka WM, Smith JNM (1991) Determinants and consequences of nestling condition in song sparrows. J Anim Ecol 60:995-1008

Houghton JT, Ding Y, Griggs DJ, Noquer M, van der Linden PJ, Dai X, Maskell K, Johnson CA (2001) Climate change 2001: the scientific basis. Cambridge University Press, Cambridge

Hughes L (2000) Biological consequences of global warming: is the signal already apparent? Trends Ecol Evol 15:56-61

Jakober H, Stauber W (2000) Werden die Neuntöter (Lanius collurio) kleiner. J Ornithol 141:408-417

Jenni L, Winkler R (1989) The feather length of small passerines: a measurement of wing length in live birds and museum skins. Bird Study 36:1-15

Jensen H, Saether BE, Ringsby TH, Tufto J, Griffith SC, Ellegren H (2003) Sexual variation in heritability and genetic correlations of morphological traits in house sparrows (Passer domesticus). J Evol Biol 16:1296-1307

Kaiser A (1992) Fat deposition and theoretical flight range of small autumn migrants in southern Germany. Bird Study 39:96-110

Kaiser A (1993) A new multi-category classification of subcutaneous fat deposits of songbirds. J Field Ornithol 64:246-255

Lehikoinen E (1987) Seasonality of the daily weight cycle in wintering passerines and its consequences. Ornis Scand 18:216-226

Leisler B, Winkler H (2003) Morphological consequences of migration in passerines. In: Berthold P, Gwinner E, Sonnenschein E (eds) Avian migration. Springer, New York, pp 175-186

Lilliendahl K (1997) The effect of predator presence on body mass in captive greenfinches. Anim Behav 53:75-81

Ludwichowski I (1997) Langfristige Trends bei Flügellänge, Körpermasse und brutbiologischen Parametern erstbrütender Weibchen eines norddeutschen Bestandes der Schellente (Bucephala clangula). Vogelwarte 39:103-116

Macleod R, Barnett P, Clark JA, Cresswell W (2005) Body mass change strategies in blackbirds Turdus merula: the starvationpredation risk trade-off. J Anim Ecol 74:292-302

McNab BK (1971) On the ecological significance of Bergmann's rule. Ecology 52:845-854

Meiri S, Dayan T (2003) On the validity of Bergmann's rule. J Biogeogr 30:331-351

Merilä J, Gustafsson L (1996) Temporal stability and microgeographic homogeneity of heritability estimates in a natural bird population. J Hered 87:199-204

Millien V, Lyons SK, Olson L, Smith FA, Wilson AB, Yom-Tov Y (2006) Ecotypic variation in the context of global climate change: revisiting the rules. Ecol Lett 9:853-869

Møller AP, Flensted-Jensen E, Mardal W (2006) Rapidly advancing laying date in a seabird and the changing advantage of early reproduction. J Anim Ecol 75:657-665

Moreno-Ruedo G, Rivas JM (2007) Recent change in allometric relationships among morphological traits in the dipper (Cinclus cinclus). J Ornithol 148:489-494 
Naef-Daenzer B, Widmer F, Nuber M (2001) Differential post-fledging survival of great and coal tits in relation to their condition and fledging date. J Anim Ecol 70:730-738

Norman SC (1997) Juvenile wing shape, wing moult and weight in the family sylviidae. Ibis 139:617-630

Norušis MJ (2005) SPSS 14.0 Advanced statistical procedures companion. Prentice Hall, Englewood Cliffs

Nowakowski JJ (2000) Long-term variability of wing length in a population of the Reed Warbler Acrocephalus scirpaceus. Acta Ornithol 35:173-182

Ohlsson T, Smith HG (2001) Early nutrition causes persistent effects on pheasant morphology. Physiol Biochem Zool 74:212-218

Parmesan C, Yohe G (2003) A globally coherent fingerprint of climate change impacts across natural systems. Nature 421:37-42

Parmesan C, Ryrholm N, Stefanescu C, Hill JK, Thomas CD, Descimon H, Huntley B, Kaila L, Kullberg J, Tammaru T, Tennent WJ, Thomas JA, Warren M (1999) Poleward shifts in geographical ranges of butterfly species associated with regional warming. Nature 399:579-583

Payette S (2007) Contrasted dynamics of northern Labrador tree lines caused by climate change and migrational lag. Ecology 88:770-780

Pehrsson O (1987) Effects of body condition on molting in Mallards. Condor 89:329-339

Peintinger M, Schuster S (2005) Veränderungen der Erstankünfte bei häufigen Zugvogelarten in Südwestdeutschland. Vogelwarte 43:161-169

Peñuelas J, Filella I, Comas P (2002) Changed plant and animal life cycles from 1952 to 2000 in the Mediterranean region. Global Change Biol 8:531-544

Pérez-Tris J, Tellerría JL (2001) Age-related variation in wing shape of migratory and sedentary blackcaps Sylvia atricapilla. J Avian Biol 32:207-213

Piersma T, Davidson NC (1991) Confusions of mass and size. Auk 108:441-443

Piersma T, Gill RE (1998) Guts don't fly: small digestive organs in obese bar-tailed godwits. Auk 115:196-203

Rensch B (1938) Some problems of geographical variation and species-formation. Proc Linn Soc Lond 150:275-285

Richner H, Schneiter P, Stirnimann H (1989) Life-history consequences of growth rate depression: an experimental study on carrion crows (Corvus corone corone L.). Funct Ecol 3:617-624

Rising JD, Somers KM (1989) The measurement of overall body size in birds. Auk 106:666-674

Root TL, Price JT, Hall KR, Schneider SH, Rosenzweig C, Pounds JA (2003) Fingerprints of global warming on wild animals and plants. Nature 421:57-60
Searcy WA, Peters S, Nowicki S (2004) Effects of early nutrition on growth rate and adult size in song sparrows Melospiza melodia. J Avian Biol 35:269-279

Smith FA, Betancourt JL (2003) The effect of Holocene temperature fluctuations on the evolution and ecology of Neotoma (woodrats) in Idaho and northwestern Utah. Quat Res 59:160-171

Smith HG, Wettermark K-J (1995) Heritability of nestling growth in cross-fostered European starlings. Genetics 141:657-665

Storz JF, Balasingh J, Bhat HR, Nathan PT, Doss DPS, Prakash AA, Kunz TH (2001) Clinal variation in body size and sexual dimorphism in an Indian fruit bat, Cynopterus sphinx (Chiroptera: Pteropodidae). Biol J Linn Soc 72:17-31

Svensson L (1992) Identification guide to European passerines. Svensson

R Development Core Team (2007) R: A language and environment for statistical computing version 2.5.1. R Foundation for Statistical Computing, Vienna

Thomas CD, Lennon JJ (1999) Birds extend their ranges northwards. Nature 399:213-213

Tornberg R, Mönkkönen M, Pahkala M (1999) Changes in diet and morphology of Finnish goshawks from 1960s to 1990s. Oecologia 121:369-376

Tøttrup AP, Thorup K, Rahbek C (2006) Patterns of change in timing of spring migration in North European songbird populations. J Avian Biol 37:84-92

Ulfstrand SU, Alatalo RV, Carlson A, Lundberg A (1981) Habitat distribution and body size of the great tit Parus major. Ibis 123:494-499

Visser ME, Both C, Lambrechts MM (2004) Global climate change leads to mistimed avian reproduction. In: Møller A, Fiedler W, Berthold P (eds) Effects of climate change in birds. Elsevier, Amsterdam, pp 89-110

Walther G-R, Post E, Convey P, Menzel A, Parmesan C, Beebee TJC, Fromentin JM, Hoegh-Guldberg O, Bairlein F (2002) Ecological responses to recent climate change. Nature 416:389-395

Wood S (2006) Generalized additive models: an introduction to R. Chapman \& Hall, CRC, London

Yom-Tov Y (2001) Global warming and body mass decline in Israeli passerine birds. Proc R Soc Lond B 268:947-952

Yom-Tov Y, Yom-Tov S (2006) Decrease in body size of Danish goshawks during the twentieth century. J Ornithol 147:644-647

Yom-Tov Y, Yom-Tov S, Wright J, Thorne CJR, Du Feu R (2006) Recent changes in body weight and wing length among some British passerine birds. Oikos 112:91-101 